\title{
Investigating the Impact of Weathering and Indoor Aging on Wood Acidity Using Spectroscopic Analyses
}

\author{
Safa Abdel-Kader Mohamed Hamed, ${ }^{\text {a }}$ Mohamed Z. M. Salem, ${ }^{\text {, } *}$ Hayssam M. Ali, ${ }^{\mathrm{c}, \mathrm{d}}$ and \\ Kareem Mohamed El-Sayed Ahmed ${ }^{\mathrm{e}}$
}

\begin{abstract}
A new perspective on the effect of unconditioned indoor (especially storage areas) and outdoor environments on wood acidity is provided in this work. A comparison between the quantity and types of the organic acids formed in the unconditioned indoor environment and different outdoor environments was made. Moreover, the acidity of some wood samples due to different environmental conditions was determined using a $\mathrm{pH}$ meter and high-performance liquid chromatography (HPLC). Fourier transform infrared (FTIR) was used to detect the changes in wood components at the molecular level due to environmental conditions. The results suggest that the unconditioned indoor environment was more aggressive than the outdoor environment with respect to wood deterioration. The polluted atmosphere increased the wood acidity and motivated polysaccharide breakdown.
\end{abstract}

Keywords: Wood degradation; Organic acids; pH; HPLC; FTIR

Contact information: a: Conservation Department, Faculty of Archaeology, Cairo University, Giza 12613, Egypt; b: Forestry and Wood Technology Department, Faculty of Agriculture (EL-Shatby), Alexandria University, Alexandria 21545, Egypt; c: Botany and Microbiology Department, College of Science, King Saud University, P.O. Box 2455, Riyadh 11451, Saudi Arabia; d: Timber Trees Research Department, Sabahia Horticulture Research Station, Horticulture Research Institute, Agriculture Research Center, Alexandria 21526, Egypt; e: Conservator at Tell-Basta, Sharqia, Ministry of Antiquities, Egypt;

*Corresponding author: zidan_forest@yahoo.com

\section{INTRODUCTION}

Wood has been recognized worldwide as a building material that has special engineering and structural properties. It has a long history of use in Egypt because many architectural elements in historic buildings are made of wood, such as ceilings, doors, floors, domes, and mashrabiyas. In addition, movable architectural elements can be found in the museum environment as objects (Hamed 2014). However, wood is susceptible to the forces of the surrounding environment such as biological agents (Mansour et al. 2020), and climate changes (Sivrikaya and Can 2016; Oberhofnerová et al. 2017). It is exposed outdoors to the deleterious effect of weathering, which can be ascribed to a complex set of reactions induced by solar radiation (UV light), moisture, oxygen, temperature, and sometimes atmospheric gaseous pollutants (Anderson et al. 1991; Ayadi et al. 2003). The combination of oxygen and solar radiation rapidly induces the oxidation of lignin and hemicellulose and depolymerization of cellulose (Lionetto et al. 2012). Furthermore, wood undergoes further degradation in the indoor environment, especially when the wooden objects displaced away from their native setting. Because the degradation mechanisms are active during long-term exhibition and storage due to temperature, moisture, and lighting effects, a stable (controlled) environment should be provided for wooden objects (Harvey 
and Freedland 1990). That is, the storage conditions determine the chemical processes that may occur in wood. Thus, they have a significant role in the aging process (Fengel 1991).

It is known that almost all types of wood have an acidic behavior that ranges from weak to moderate. The source of wood acidity is the acidic wood components, i.e., the acetyl groups and uronic acid residues attached to the polyoses (xylans in hardwood and mannans in softwood) (Anderson et al. 1991). While many of the organic acids are found bound as esters, some of them exist in the form of salts, and a few of them are found as free acids (Fengel and Wegener 1984; Matteoli et al. 1992; Balaban and Uçar 2001; Yaşar 2018).

Wood has several weak acids or acidic groups, but the most acidic ones control its acidity (Uçar and Uçar 2012). Furthermore, there is no correlation between wood acidity and the content of volatile acids (Balaban and Uçar 2003).

Most of the studies investigating the acidic behavior of wood address volatile organic acids, basically formic and acetic, and they have neglected the others that increase the acidity, notably those resulting from the degradation of wood components due to the changing environment. Thus, the purpose of this investigation is to determine the wood acidity and the differences in the organic acids within wood due to the exposure to different environmental conditions. The conditions considered included indoor $v s$. outdoor environments and polluted and highly populated areas.

\section{EXPERIMENTAL}

\section{Wood Samples}

Wooden samples (Table 1) were collected in August 2018 from architectural elements in different places. Four samples were taken from objects stored in the museum storage at the Faculty of Archaeology, Cairo University, Giza, which is the third largest city in Egypt. One sample was taken from Al-Jawhara Palace located in Salah El-Din Citadel in Cairo. Two samples were taken from different buildings on El-Moez street, surrounded by densely populated areas in all directions and considered one of the oldest streets in Cairo. Moreover, two samples were taken from palaces located in Helwan, which is heavy industrial and residential site that lies in south east of Cairo city and is considered the main air pollution source in Cairo according to Alkhdhairi et al. (2018).

Table 1. Sample Numbers with their Locations and Codes Measured in the Present Work

\begin{tabular}{|c|l|c|}
\hline $\begin{array}{c}\text { Sample } \\
\text { No. }\end{array}$ & Location & $\begin{array}{c}\text { Sample } \\
\text { code }\end{array}$ \\
\hline 1 & Museum Indoor Environment, Giza & MIE1 \\
\hline 2 & Museum Indoor Environment, Giza & MIE2 \\
\hline 3 & Museum Indoor Environment, Giza & MIE3 \\
\hline 4 & Museum Indoor Environment, Giza & MIE4 \\
\hline 5 & Al-Jawhara Palace located in Salah El-Din Citadel in Cairo & OEJ \\
\hline 6 & El-Moez street, Cairo & OEM1 \\
\hline 7 & El-Moez street, Cairo & OEM2 \\
\hline 8 & Helwan Palace & OEH1 \\
\hline 9 & Helwan Palace & OEH2 \\
\hline 10 & Artificially seasoned new wood & ASNW \\
\hline 11 & Naturally aged wood block (50 years) & NAW \\
\hline
\end{tabular}


The annual climatic (humidity and temperature) variations to the places where samples were collected were in Cairo with average temperature ranging between max. $37^{\circ}$ $\mathrm{C}\left(99^{\circ} \mathrm{F}\right)$ and $\min .22^{\circ} \mathrm{C}\left(71.8^{\circ} \mathrm{F}\right)$ and average relative humidity $46 \%$, in Giza with average temperature ranging between max. $35^{\circ} \mathrm{C}\left(96^{\circ} \mathrm{F}\right)$ and min. $24^{\circ} \mathrm{C}\left(76^{\circ} \mathrm{F}\right)$ and average relative humidity $46 \%$ and, in Helwan with average temperature ranging between max. 37 ${ }^{\circ} \mathrm{C}\left(99^{\circ} \mathrm{F}\right)$ and $\min .24{ }^{\circ} \mathrm{C}\left(76^{\circ} \mathrm{F}\right)$ and average relative humidity $45 \%$.

For comparison, artificially seasoned new wood blocks (ASNW) and naturally aged wood (NAW) blocks, for 50 years, were cut (approximately $15 \times 5 \times 5 \mathrm{~cm}^{3}$ ). The two collected wood blocks from each sample as well as ASNW and NAW blocks were milled and ground to fine powder using a laboratory Wiley mill (A-47054; Weverk, Karlstad, Sweden) (Salem et al. 2020). Then, the wood powders were screened to obtain 20-mesh sized samples, which were used for the chemical analysis.

\section{Optical Microscopy}

Optical microscopy (OM) was used to examine the prepared sections of the collected wooden samples to identify their species. Optical microscopy images were taken with a Zeiss Stereo DV 20 microscope equipped with an Axio Cam MRC5 (Zeiss, Oberkochen, Germany).

\section{Scanning Electron Microscopy (SEM)}

In order to detect any fungal decay that can affect the results, small pieces $(2 \times 2 \times$ $5 \mathrm{~mm}^{3}$ ) were removed from the collected wood samples, then they were mounted on aluminium stubs with double-sided cellophane tape and they were coated with gold (K550X sputter coater; EMITECH, Ashford, England). Finally, they were examined by SEM (JEOL scanning electron microscope JXA-840A; JEOL Ltd.).

\section{Determination of $\mathrm{pH}$ Value}

For $\mathrm{pH}$ measurement, the wood samples were ground. A total of $2.5 \mathrm{~g}$ of oven-dried sawdust of each sample were weighed and soaked in $25 \mathrm{~mL}$ of distilled water and left at room temperature overnight. Then, they were mixed well via stirring and filtered with filter papers. After that, the $\mathrm{pH}$ values of the filtrate (the liquid) were determined using a $\mathrm{pH}$ meter (BOECO, 20422, Boeckel + Co (GmbH + Co) KG, Hamburg, Germany) (Mansour et al. 2020).

\section{Preparation of Sample and Organic Acids Extraction}

Eleven samples (nine collected samples, ASNW, and NAW) in the form of powered materials (20 mesh) were each weighed out as $0.1 \mathrm{~g}$ and used for the extraction and analysis (Clausen et al. 2008). The extraction was completed with $\mathrm{H}_{2} \mathrm{SO}_{4}(0.1 \mathrm{~N})$ for $1 \mathrm{~h}$ at $25^{\circ} \mathrm{C}$ using rotary mixing, then centrifuged $(21,000 \times \mathrm{g}, 10 \mathrm{~min})$ and filtered through a $0.45-\mu \mathrm{m}$ filter (Kenealy et al. 2007).

\section{High-performance Liquid Chromatography (HPLC)}

High-performance liquid chromatography was used to separate and quantify the organic acids in the wooden samples under investigation. Chromatographic separation of organic acids was performed using an HPLC Knauer (Wissenschaftliche Geräte GmbH, Berlin, Germany) with a Rezex@ column (Phenomenex, USA catalogue, 2014/2015) equipped with a binary pump. The flow rate was set at $0.6 \mathrm{~mL} / \mathrm{min}$, the UV detector was set at $214 \mathrm{~nm}$, and the column oven temperature was kept constant at $65{ }^{\circ} \mathrm{C}$. The column 
used was a Rezex@ column for organic acids analysis, and the mobile phase was $0.005 \mathrm{M}$ $\mathrm{H}_{2} \mathrm{SO}_{4}$. Data were integrated by ClarityChrom@ Version 7.2.0, Chromatography Software (KnauerWissenschaftliche Geräte GmbH, Berlin, Germany). Standard organic acids of analytical grade of oxalic, citric, tartaric, succinic, glutaric, acetic, propionic, and butyric acids were used for the HPLC analysis (Mansour et al. 2020).

\section{Fourier Transform Infrared Spectroscopy (FTIR)}

The FTIR spectra of the selected samples were collected using an FTIR spectrophotometer (Nicolet 380; Thermo Fisher Scientific, Waltham, MA, USA) The potassium bromide disk containing finely ground samples was prepared and then analyzed and recorded in the transmission mode within the frequency range of 4000 to $400 \mathrm{~cm}^{-1}$. All spectra were recorded at $4 \mathrm{~cm}^{-1}$ resolution. The peak heights and width of absorption bands were measured by the essential FTIR (eFTIR) software (Operant LLC, version 3.50, Burke, VA, USA).

\section{RESULTS AND DISCUSSION}

\section{Identification of Wood Samples}

The microscopic examination indicated that the wooden samples were identified as pine (Pinus sp.), where the diagnostic characteristics (Fig. 1) showed that growth ring boundaries were distinct - latewood tracheids thick walled and axial intercellular resin canals present with epithelial cells thin walled in the transverse section (TS). In addition, the tangential longitudinal section (TLS) showed uniseriate rays with a medium average height (5 to 15 cells) and radial intercellular resin canals. In the radial longitudinal section (RLS), the ray tracheid commonly presented with dentate cell walls and ray parenchyma's end walls were smooth (Crivellaro and Schweingruber 2013).
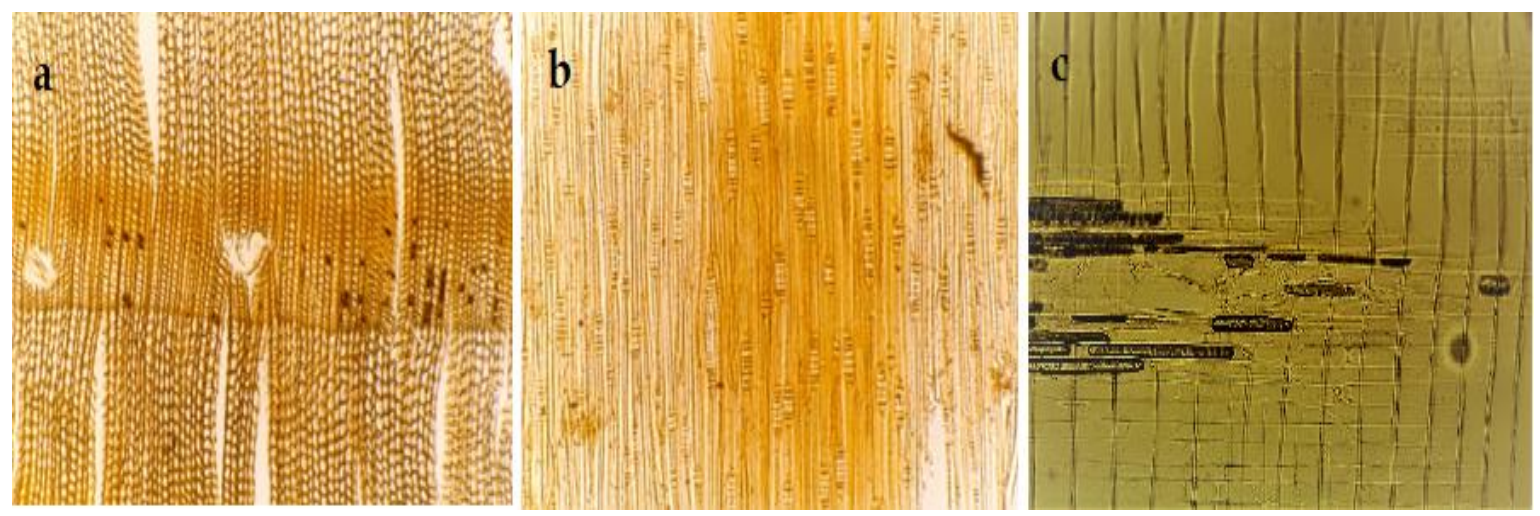

Fig. 1. The anatomical characteristics of the wooden samples collected for this study that identified as Pinus sp. by optical microscopy in transmitted light: A- Transverse section; BTangential section; and C- Radial section

\section{Scanning Electron Microscope Analysis}

Scanning electron microscope micrographs (Fig. 2) revealed the presence of nonbiological deterioration in the examined wood samples, mostly resulting from weathering and mechanical deterioration, which are considered the most important factors for architectural wooden elements according to their location and their function. Moreover, 
the micrographs confirmed the absence of fungal attack. Sustained cracks, fractures, and separations along the cell walls were evident in all samples due to loads and stresses that the wooden elements are exposed to. In addition, the damage results from weathering can be seen in the form of extraneous material presence, destruction of bordered pits, and cell wall checking.
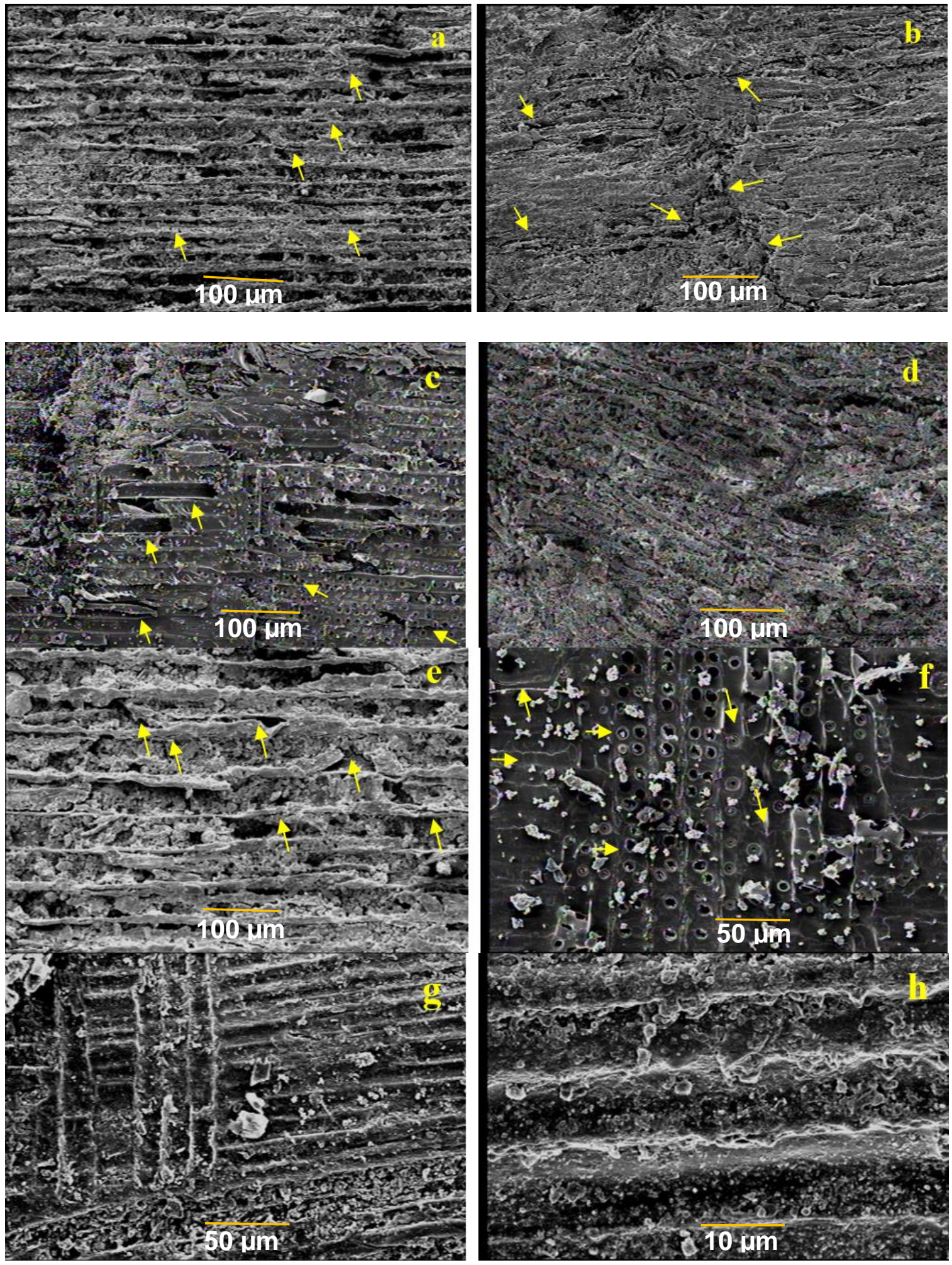

Hamed et al. (2020). "Weathering \& wood acidity," BioResources 15(3), 6506-6525.

6510 


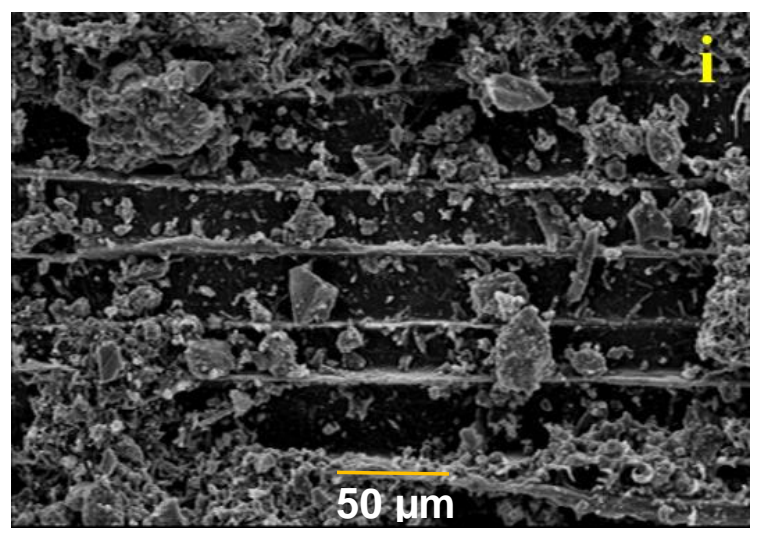

Fig. 2. SEM micrographs of the collected wooden samples show the mechanical deterioration due to loads and stresses and the impact of weathering on the anatomical structure of wood, where; (a) sample MIE1, (b) sample MIE2, (c) sample MIE3, (d) sample MIE4, (e) sample OEJ, (f) sample OEM1, (g) sample OEM2, (h) sample OEH1, and (i) sample OEH2. Arrow symbol refers to cracks, fractures, and separations along the cell walls that were evident in all samples due to loads and stresses that the wooden elements were are exposed to. Destruction of bordered pits and cell wall checking appeared in sample OEM1.

\section{pH Values of the Collected Wood Samples}

As shown in Table 2, the $\mathrm{pH}$ value differed in the collected samples. Surprisingly, two samples from the objects stored at the museum (samples MIE and MIE2), that were subjected to an uncontrolled indoor environment, exhibited more acidity than the samples in the building's structure and subjected to outdoor environment (samples OEJ, OEM1, $\mathrm{OEM} 2$, OEH1, and $\mathrm{OEH} 2$ ). However, these building are sometimes located in industrial cities, e.g., Helwan (samples OEH1 and OEH2) and polluted atmosphere (samples OEJ and OEM1), indicating that the unsuitable conditions in the museum halls and storage areas can enhance acid formation in wood more than polluted atmospheres. The increased $\mathrm{pH}$ value (pH: 7.04) of sample OEM2 may be because the sewage system in this zone is poor, as well as the fact that in 2012 broken sewage systems flooded the street for days, and this leaking liquid, which was highly alkaline, was absorbed by the buildings in this zone.

Table 2. pH Values of the Wooden Samples Applied in this Study

\begin{tabular}{|c|c|}
\hline Sample No. & pH Value \\
\hline MIE1 & 5.15 \\
\hline MIE2 & 5.11 \\
\hline MIE3 & 6.12 \\
\hline MIE4 & 6.16 \\
\hline OEJ & 5.77 \\
\hline OEM1 & 5.79 \\
\hline OEM2 & 7.04 \\
\hline OEH1 & 5.32 \\
\hline OEH2 & 5.38 \\
\hline
\end{tabular}

\section{HPLC Analysis of Organic Acids}

According to the HPLC analysis of organic acids in nine wooden samples (Fig. 3), seven acids were identified (Table 3). While oxalic acid represented the major identified organic acid in all samples, the highest amounts were observed in the samples MIE1, MIE2, and MIE4 followed by naturally aged pine wood and sample MIE3 with values of $(\mathrm{mg} / \mathrm{g}$ 
oven-dry (o.d.) sample) 217, 100.5, 97.6, 96.9, and 93.2, respectively. Additionally, glutaric acid was found with high amounts in the naturally aged wood $(114.6 \mathrm{mg} / \mathrm{g}$ o.d. sample), artificially seasoned pine wood ( $81.8 \mathrm{mg} / \mathrm{g}$ o.d. sample), and in sample MIE1 (43.9 $\mathrm{mg} / \mathrm{g}$ o.d. sample). In addition, chromatogram peaks that suggested the presence of citric, tartaric, and succinic acids were noticed in some samples. Citric acid was observed in sample MIE1 (34.1 mg/g o.d. sample), artificially seasoned pine wood $(11.7 \mathrm{mg} / \mathrm{g}$ o.d. sample), and sample MIE2 (0.67 mg/g o.d. sample), but it was missing in other samples. Tartaric acid was found in samples OEM1 $(0.21 \mathrm{mg} / \mathrm{g}$ o.d. sample) and OEH1 $(0.47 \mathrm{mg} / \mathrm{g}$ o.d. sample), while succinic acid was only present in sample MIE1 (147.25 mg/g o.d. sample).

Table 3. HPLC Analysis of Organic Acids of the Collected Wooden Samples of

Pine

\begin{tabular}{|c|c|c|c|c|c|c|c|c|c|}
\hline \multirow{2}{*}{$\begin{array}{c}\text { Sample } \\
\text { No. }\end{array}$} & \multicolumn{10}{|c|}{$\begin{array}{c}\text { Oxalic } \\
\text { Acid }\end{array}$} & $\begin{array}{c}\text { Citric } \\
\text { Acid }\end{array}$ & $\begin{array}{c}\text { Tartaric } \\
\text { Acid }\end{array}$ & $\begin{array}{c}\text { Succinic } \\
\text { Acid }\end{array}$ & $\begin{array}{c}\text { Glutaric } \\
\text { Acid }\end{array}$ & $\begin{array}{c}\text { Acetic } \\
\text { Acid }\end{array}$ & $\begin{array}{c}\text { Butyric } \\
\text { Acid }\end{array}$ & $\begin{array}{c}\text { Propionic } \\
\text { Acid }\end{array}$ & $\begin{array}{c}\text { Malic } \\
\text { Acid }\end{array}$ \\
\hline MIE1 & 217 & 34.13 & ND & 147.25 & 43.88 & ND & ND & 0.27 & ND \\
\hline MIE2 & 100.49 & 0.67 & ND & 2.05 & 4.02 & ND & ND & ND & ND \\
\hline MIE3 & 93.21 & ND & ND & ND & ND & ND & ND & ND & ND \\
\hline MIE4 & 97.557 & ND & ND & ND & 4.962 & 0.292 & ND & ND & ND \\
\hline OEJ & 22.73 & ND & ND & ND & ND & ND & 0.005 & ND & ND \\
\hline OEM1 & 22.65 & ND & 0.21 & ND & 0.51 & ND & ND & ND & ND \\
\hline OEM2 & 4.75 & ND & ND & ND & ND & ND & ND & ND & ND \\
\hline OEH1 & 61.93 & ND & 0.47 & ND & 0.59 & 0.001 & 0.003 & ND & ND \\
\hline OEH2 & 27.85 & ND & ND & ND & 0.99 & ND & ND & ND & ND \\
\hline ASNW & 71.615 & 11.727 & ND & ND & 81.82 & ND & ND & 0.06 & 7.607 \\
\hline NAW & 96.86 & ND & ND & ND & 114.64 & 0.011 & ND & 0.389 & 54.764 \\
\hline
\end{tabular}

ASNW) artificially seasoned new wood blocks; NAW) naturally aged wood block for 50 years; NDnot determined

Unexpectedly, acetic and butyric acids were missing in nearly in all the samples, except for sample MIE4, in which acetic acid was observed in a low amount $(0.292 \mathrm{mg} / \mathrm{g}$ o.d. sample). While traces of acetic acid (sample OEH1 and naturally aged pine wood) and butyric acid (samples OEJ and OEH1) could be noticed. Sample MIE2 showed the highest quantities of oxalic acid. It was followed by samples MIE3and OEH1, sequentially, while samples OEJ, OEM1, and OEH2 showed almost the same quantities. The sample OEM2, which exhibited neutral behavior, showed the lowest quantity of oxalic acid. 

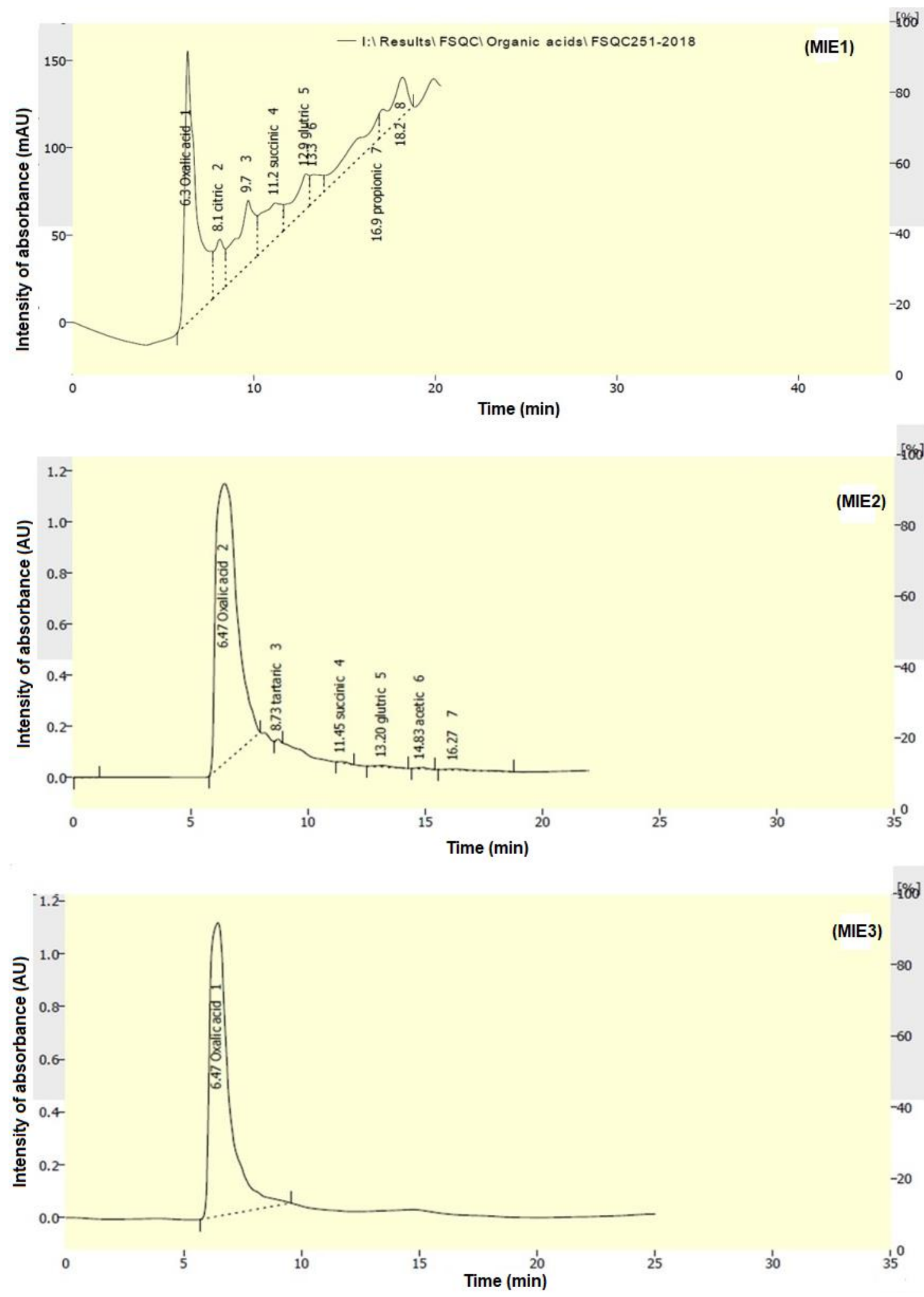

$-100$

(MIE3) 


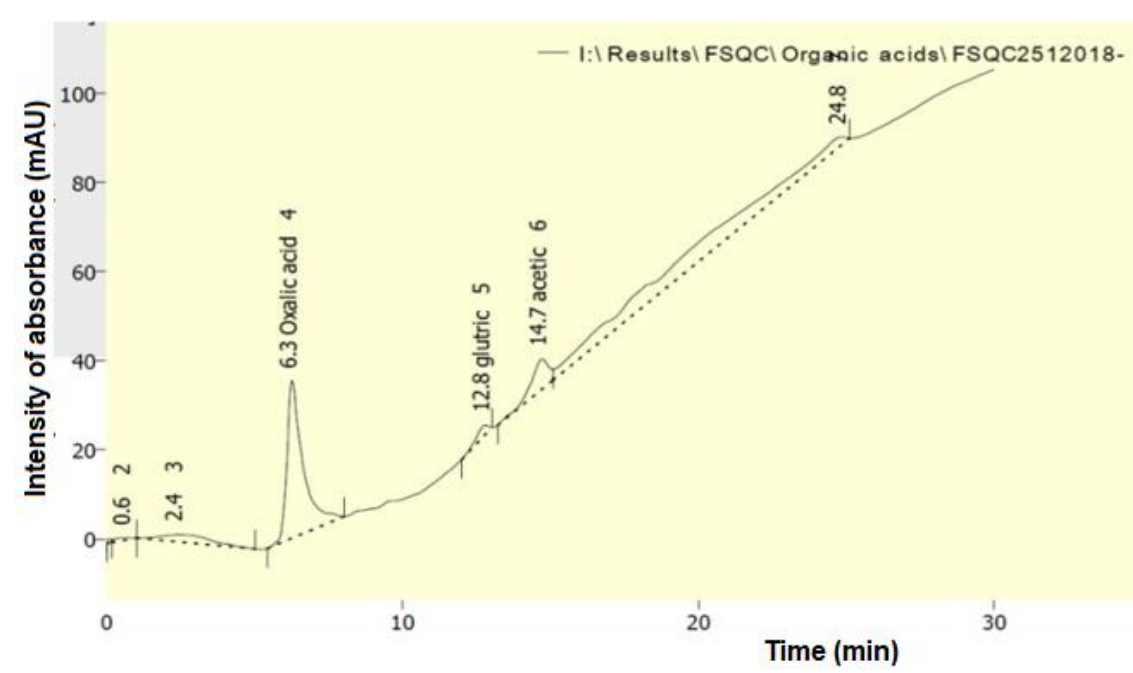

(MIE4)
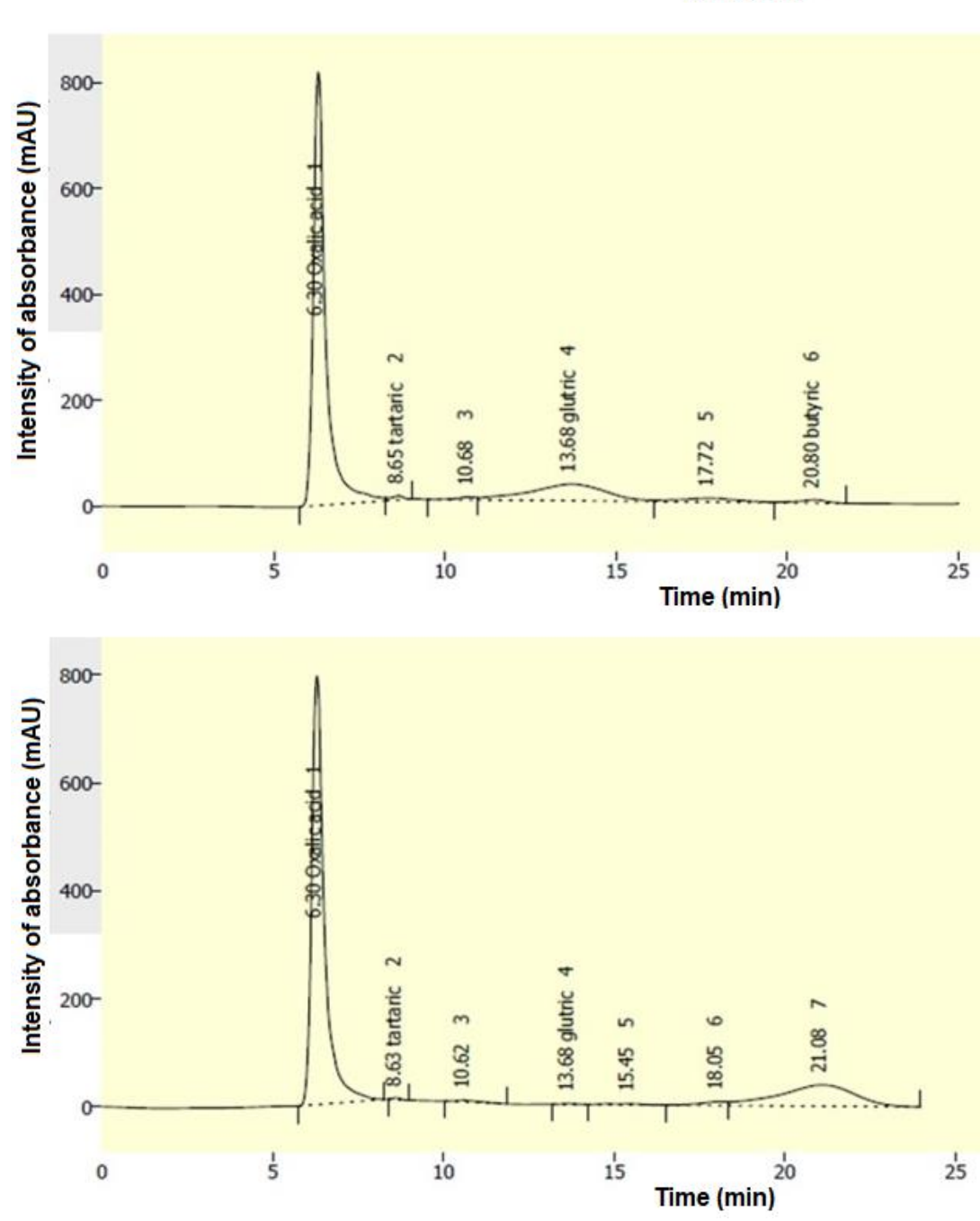

30 

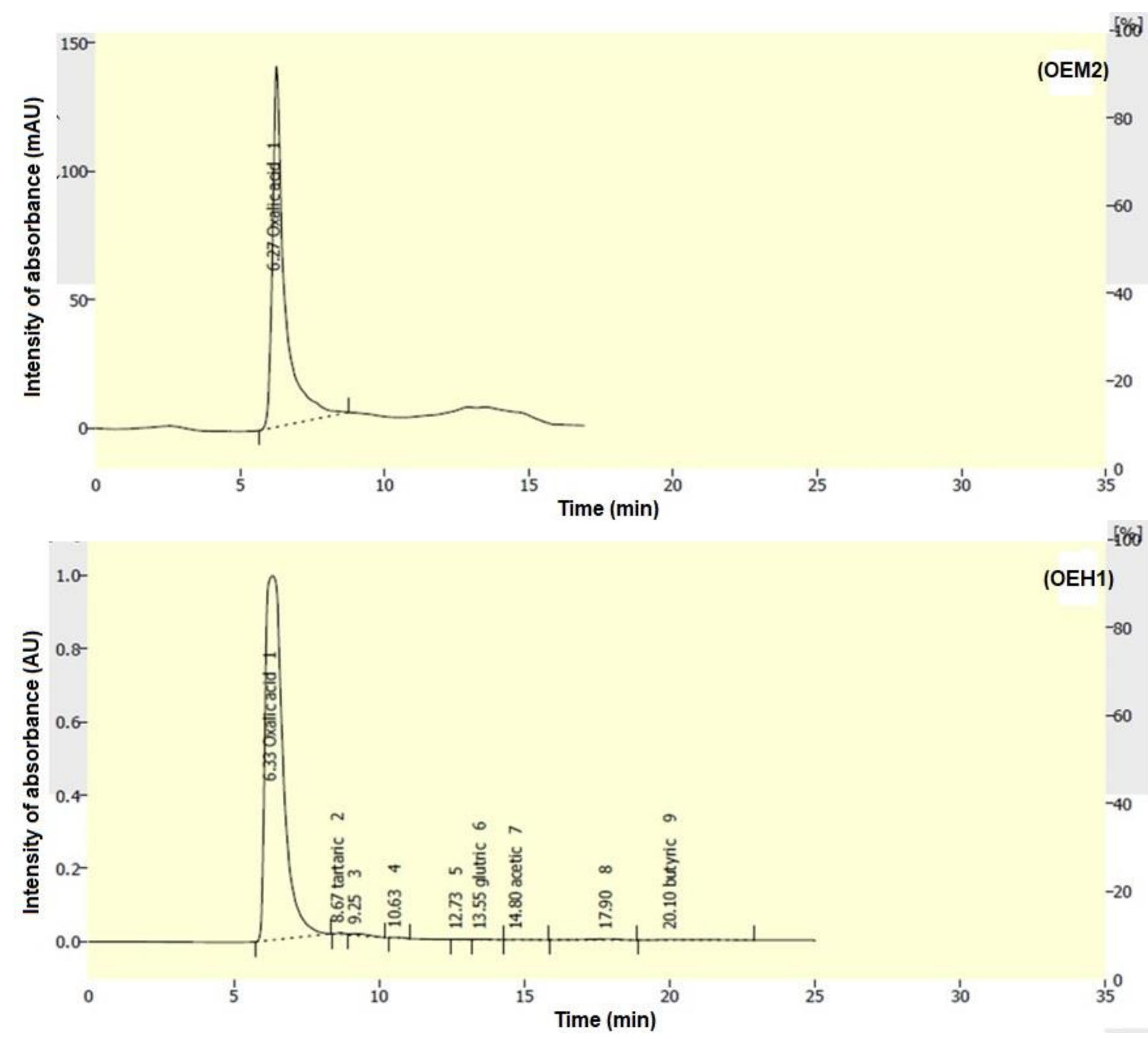

(OEH1)

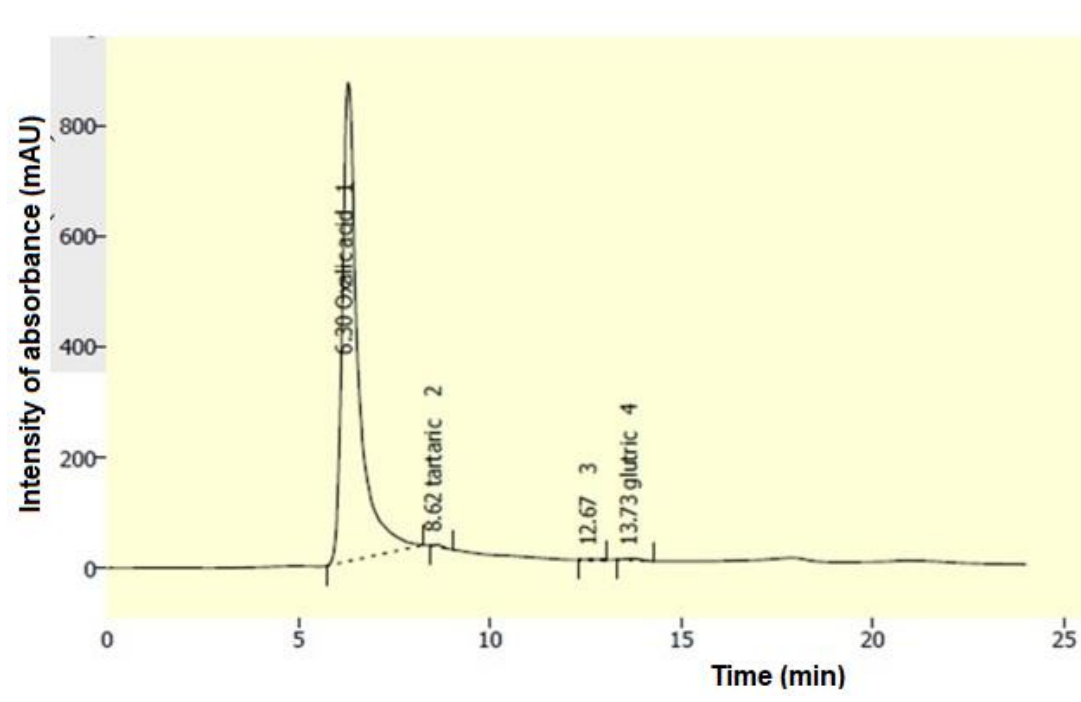

$-1 \% 0$

(OEH2) 

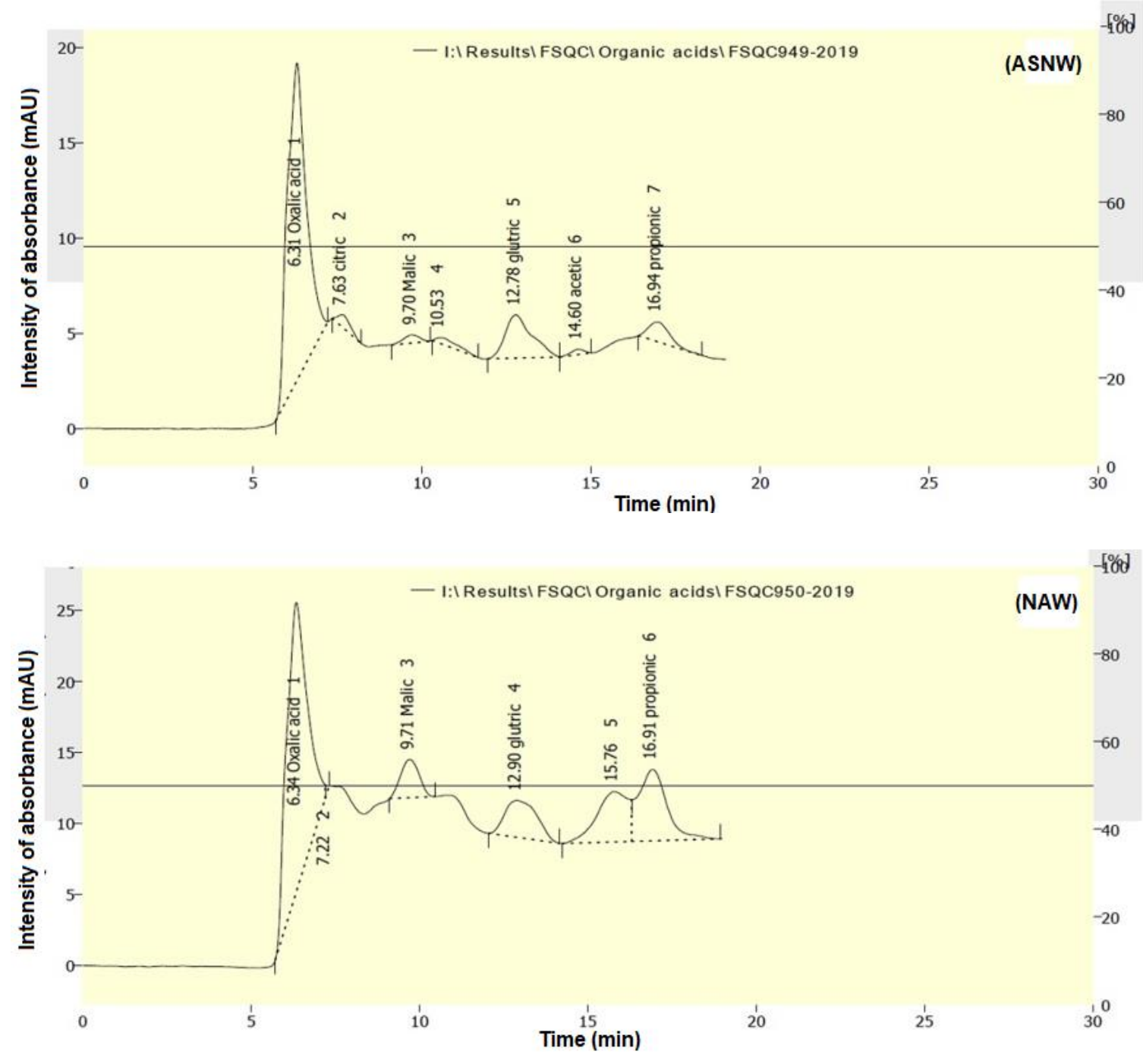

Fig. 3. Chromatogram of HPLC analysis of organic acids in the collected wooden samples from (MIE1 to OEH2, (ASNW) artificially seasoned new wood blocks; (NAW) naturally aged wood block for 50 years

The results showed that sample MIE2 contained the highest quantity of oxalic acid and glutaric acids comparatively. Moreover, it is the only sample that had citric and succinic acids. Sample OEH1, unlike the other samples, contained five organic acids. In addition to the oxalic acid, small quantities of tartaric, glutaric, acetic, and butyric acids were present in the samples. The sample OEJ shows a small amount of tartaric and glutaric acids.

\section{FTIR Analysis}

The collected samples were analyzed using FTIR to detect the changes in wood components at the molecular level. The main results obtained showed changes in the characteristic IR bands of pine wood (Fig. 4). That is, the indoor and outdoor environmental conditions had a significant effect on the functional groups of the wood surface. 

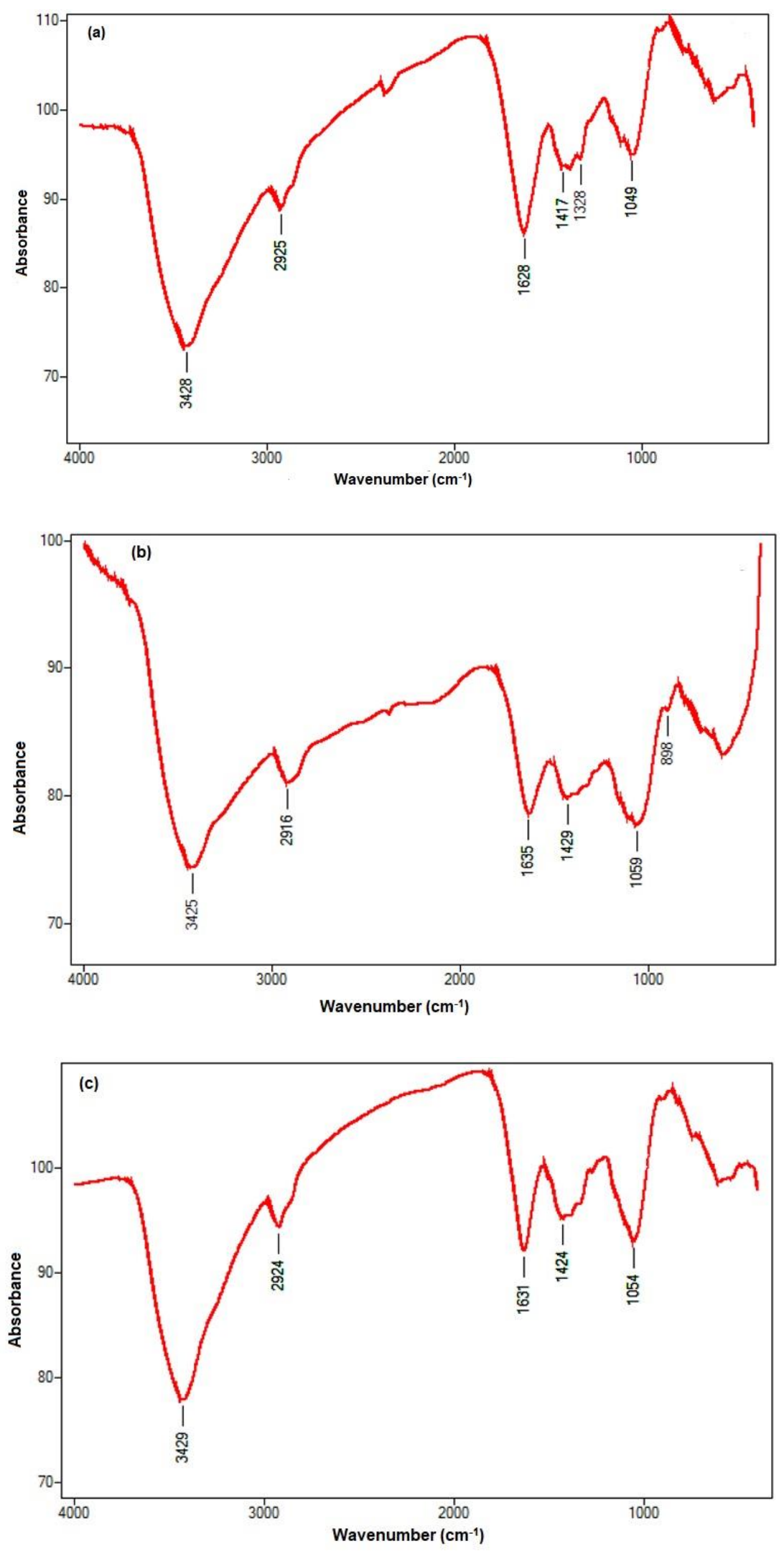

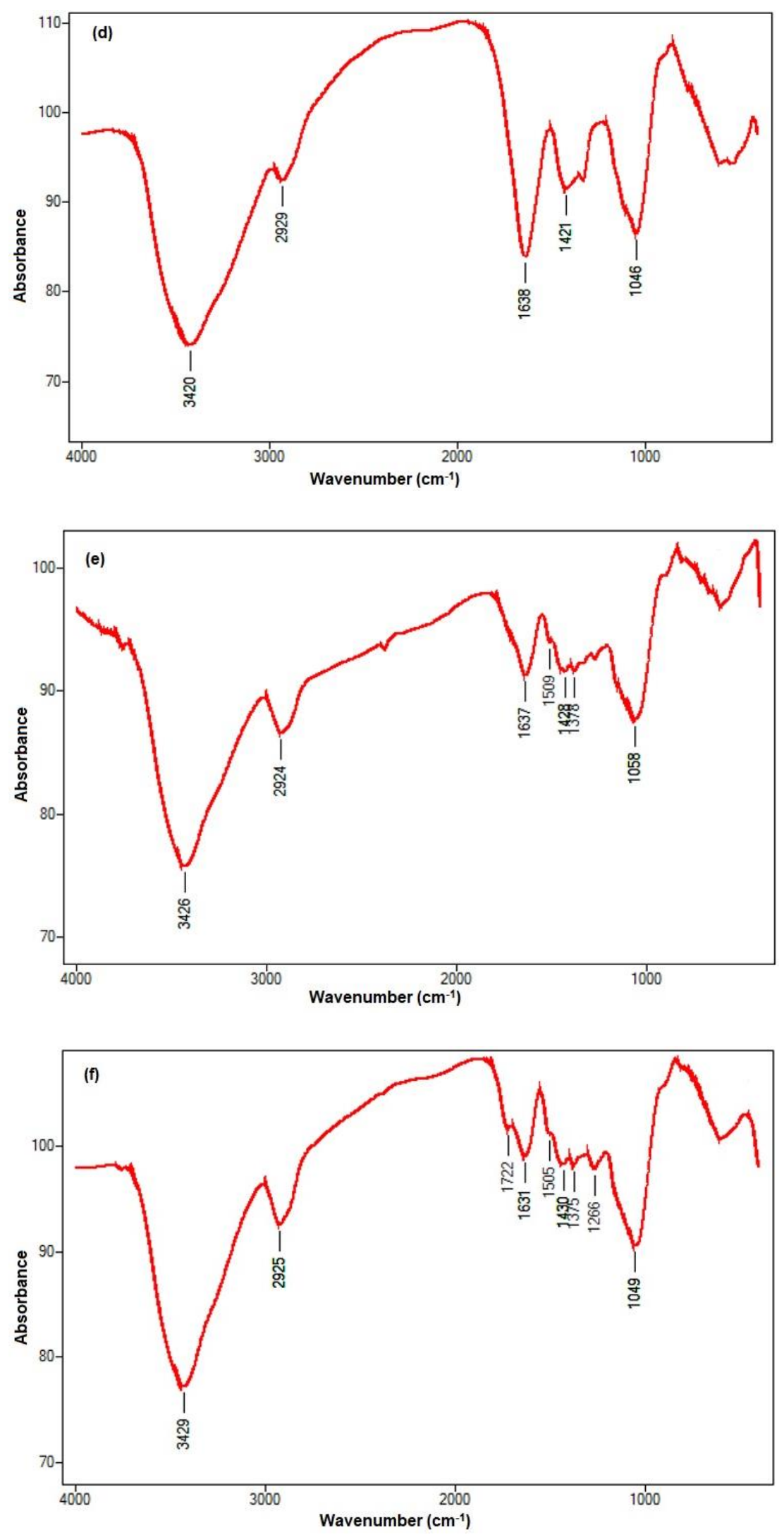

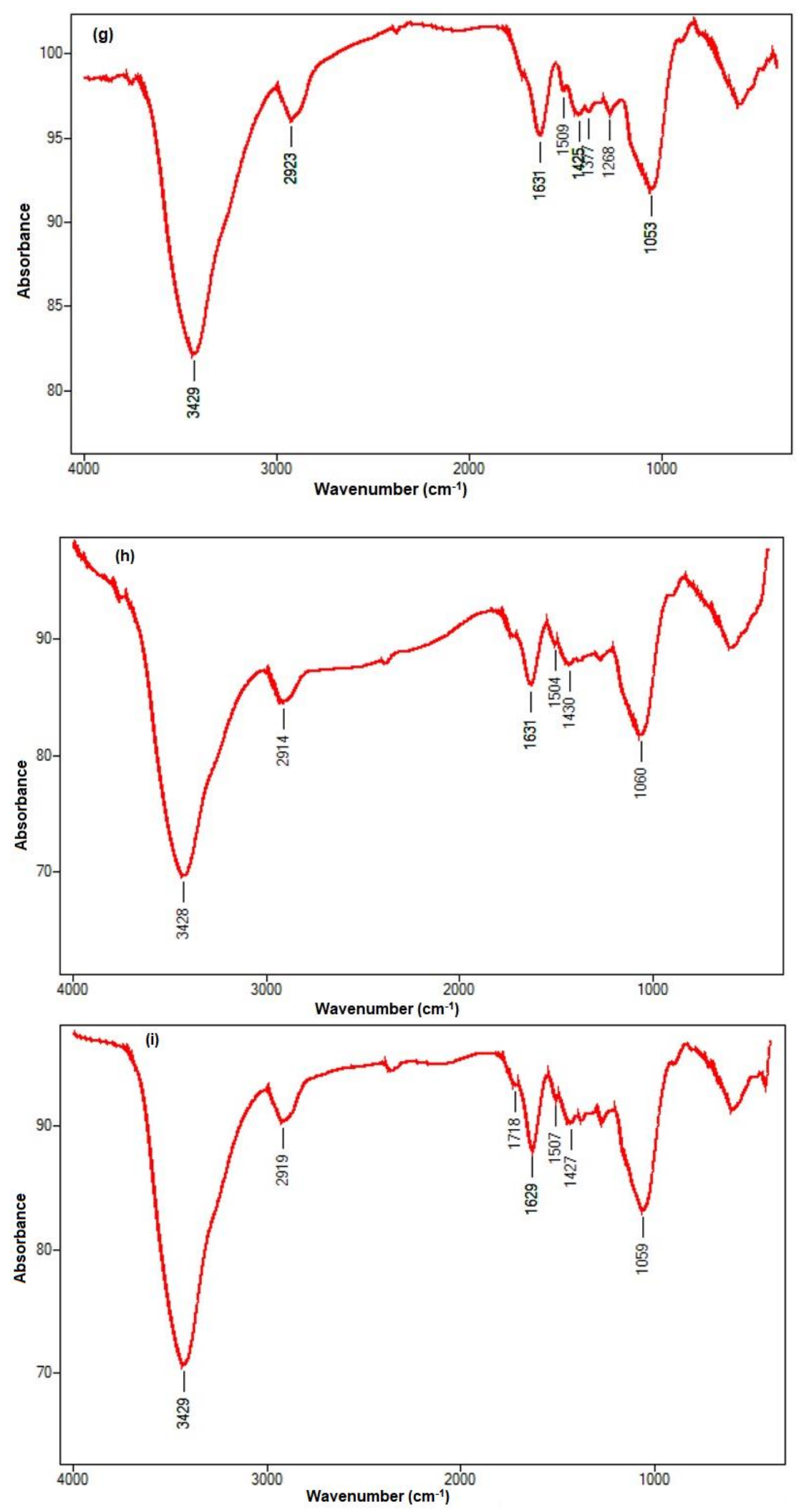

Fig. 4. FTIR spectra of the selected wooden samples, where: (a) sample MIE1, (b) sample MIE2, (c) sample MIE3, (d) sample MIE4, (e) sample OEJ, (f) sample OEM1, (g) sample OEM2, (h) sample OEH1, and (i) sample OEH2 
The band at 1730 to $1740 \mathrm{~cm}^{-1}$ attributed to hemicellulose disappeared in all samples except for a shoulder around $1730 \mathrm{~cm}^{-1}$ in samples OEJ, OEM1, OEM2, OEH1, and $\mathrm{OEH} 2$. Drastic decrease or absence in typical bands was assigned to cellulose. The band at $1425 \mathrm{~cm}^{-1}$, assigned to amorphous and crystalline cellulose, was absent in samples MIE1 and MIE2, but it slightly shifted to a higher wavelength in the other samples. The band at $1375 \mathrm{~cm}^{-1}$ disappeared in samples MIE1, MIE2, MIE3, and MIE4, while it was weak in the other samples. The absence of the C-O-C peak at $1150 \mathrm{~cm}^{-1}$ to $1165 \mathrm{~cm}^{-1}$ could be observed, indicating a loss in the cellulose polymerization in the investigated samples. In addition, there was a notable reduction in the intensity of the absorption at $897 \mathrm{~cm}^{-1}$.

However, a significant change in typical bands of lignin at $1600 \mathrm{~cm}^{-1}, 1510 \mathrm{~cm}^{-1}$, $1457 \mathrm{~cm}^{-1}$, and $1269 \mathrm{~cm}^{-1}$ was observed. The lignin bands were absent at $1600 \mathrm{~cm}^{-1}$ and $1457 \mathrm{~cm}^{-1}$ in all samples, but they disappeared in samples MIE1, MIE2, MIE3, and MIE4. While there was a significant decrease in absorbance values at $1510 \mathrm{~cm}^{-1}$, a shift to a lower wavelength in samples OEJ, OEM1, OEM2, and OEH2 could be noticed, and it disappeared in sample OEH1. The vibrations of the guaiacyl rings and stretching vibrations of the $\mathrm{C}$ to $\mathrm{O}$ bond at $1269 \mathrm{~cm}^{-1}$ showed an absorbance reduction in samples OEJ and OEH1. The bound water bands at $3432 \mathrm{~cm}^{-1}$ and $1634 \mathrm{~cm}^{-1}$ showed changes due to various moisture levels in the samples.

The results indicated that the unsuitable environmental conditions in the museum halls and storage areas could enhance acid formation in wood more than the polluted atmospheres. This may be due to elevated temperatures in the unconditioned storage area, especially in summer; the longest season in Egypt (Sundqvist 2004). Moreover, the high temperature with humid conditions provoke wood acidification to the greatest extent and liberate the organic acids (Straže et al. 2003).

Wood is naturally acidic, and this is related to the free and bound organic acids of extractives, noncellulosic polysaccharides and phenolic constituents (Metsämuuronen and Sirén 2019; Ashmawy et al. 2020; EL-Hefny et al. 2020). These components have particular importance in the different acidity between wood species depending on their quantity and kinds (Fengel and Wegener 1984; Matteoli et al. 1992; Balaban and Uçar 2001; Yaşar 2018; Mansour et al. 2020).

The identified acids are normally found in wood tissue (Krilov and Lasander 1988). Oxalic acid is always the most abundant diacid as fast secondary productions in wood, whatever site and season, with a relative abundance higher than 60\% (Legrand et al. 2007). Through the cyclohexene-ozone system, malonic and oxalic acids are also produced (Kalberer et al. 2000). Malonic acid (pine wood) and succinic acid (oak wood) were also emitted by wood burning (Rogge et al. 1998).

The absence of acetic and formic acids can be attributed to their nature as volatile organic acids and the considerable differences in the rates of acetic acid production between wood species depending on the proportion of acetyl groups that can liberate acetic acid. It is higher in hardwood than in softwood (Matteoli et al. 1992). Moreover, the rate of acetic acid formation depends on the temperature and the moisture content of the wood, while its liberation rate depends on the geometry of the wooden object. This finding matches the results of Risholm-Sundman et al. (1998), emphasizing the absence of acetic acid in softwood at room temperature. Pine wood showed the presence of citric acid in the amount of $3.61 \mathrm{~g} / \mathrm{kg}$ as observed by the enzymatic hydrolysis (Sirén et al. 2015).

The results show that sample MIE2, which exhibited more acidity than the other samples, contained the highest amount of oxalic acid and glutaric acids. It is the only 
sample that has citric and succinic acids, as shown by FTIR analysis. The absence of all the typical bands of lignin (Huang et al. 2012) in samples MIE1, MIE2, MIE3, and MIE4 suggests severe degradation of lignin, because oxalic and succinic acids are the major oxidation products of lignin (Demesa et al. 2015; Bi et al. 2017; Cronin et al. 2017).

In addition, the absorbance reduction of the guaiacyl rings (Emandi et al. 2011) in samples OEJ, OEM1, OEM2, and OEH2 can be due to weathering (Tolvaj and Faix 1995). The absence of hemicellulose in all samples is due to the degradation of acetyl groups. Moreover, the presence of a shoulder around $1730 \mathrm{~cm}^{-1}$ in samples OEJ, OEM1, OEM2, $\mathrm{OEH} 1$, and $\mathrm{OEH} 2$ may be due to oxidized cellulose and lignin during weathering (Xie et al. 2005; Temiz et al. 2006; Fackler et al. 2011).

The absence of the cellulose band at $1425 \mathrm{~cm}^{-1}$ in samples MIE1 and MIE2 suggests dramatic degradation of cellulose due to acidity. Shifting this band to a higher wavelength in the other samples can be explained according to Colom et al. (2003) by the intensive decreasing of the amorphous area of the cellulosic component during the degradation process or the capability of partially degraded cellulose to form new and larger crystals. Regarding the absence and weakness of cellulose bands, the results emphasize that the organic acids promote the degradation rate of polysaccharides (Sundqvist et al. 2006).

According to the changes in water bands, the results indicate that samples taken from the objects preserved in the museum show higher moisture level than those taken from the wooden elements of the building's structure (Emandi et al. 2011).

Finally, the results show that the unconditioned indoor environment is more aggressive than the outdoor environment because it increases the acidity of wood. This finding could be interpreted that the organic acids that are emitted from wood are effective in the indoor environment (Risholm-Sundman et al. 1998), and the acid liberation takes place under the damp conditions of storage. This action increases in high temperature (Straže et al. 2003). Therefore, the synergy of forces in the indoor environment can be worse than weathering. In addition, the exposure to the polluted atmosphere increases the effect of weathering and enhances the breakdown of polysaccharides (Mader et al. 1955; Malhotra and Khan 1984). Furthermore, the environmental pollutant gases that are claimed to diffuse into the wooden material indoor environment include those present in the outdoor macroenvironment (gallery and storage spaces) such as nitrogen oxides, ozone and other photochemical oxidants, sulfur dioxide, and particles, and indoor-generated pollutants in the microenvironment (display cases and storage cabinets) include formaldehyde, acetaldehyde, and formic and acetic acids.

\section{CONCLUSIONS}

This work attempted to examine the effect of weathering in varying environments on wood acidity. The collected samples were examined by the optical microscope to identify the wood species. Three methods of analysis were used to determine the $\mathrm{pH}$ value, the quantity and types of organic acids, and the changes in the wood components at the molecular level due to acidity. The following points summarize the findings:

1. The results suggest that the unconditioned indoor environment provokes acid formation and its impact on wood components is higher than that of the outdoor environment that causes weathering.

2. Meanwhile, polluted atmosphere can have almost the same effect as indoor conditions with respect to the effects on wood polysaccharides. 


\section{ACKNOWLEDGMENTS}

This research was funded by the Researchers Supporting Project (RSP-2020/123) from King Saud University, Riyadh, Saudi Arabia.

\section{REFERENCES CITED}

Alkhdhairi, S. A., Abdel-Hameed, U. K., Morsy, A. A., and Tantawy, M. E. (2018). "Air pollution and its impact on the elements of soil and plants in Helwan area," International Journal of Advanced Research in Biological Sciences 5(6), 38-59. DOI: http://dx.doi.org/10.22192/ijarbs.2018.05.06.004

Anderson, E. L., Pawlak, Z., Owen, N. L., and Feist, W. C. (1991). "Infrared studies of wood weathering. Part I: Softwoods," Applied Spectrosc. 45(4), 641-647. DOI: 10.1366/0003702914336930

Ashmawy, N. A., Salem, M. Z. M., El Shanhorey, N., Al-Huqail, A., Ali, H. M., and Behiry, S. I. (2020). "Eco-friendly wood-biofungicidal and antibacterial activities of various Coccoloba uvifera L. leaf extracts: HPLC analysis of phenolic and flavonoid compounds," BioResources 15(2), 4165-4187. DOI: 10.15376/biores.15.2.4165-4187

Ayadi, N., Lejeune, F., Charrier, F., Charrier, B., and Merlin, A. (2003). "Color stability of heat-treated wood during artificial weathering," Holz. Roh. Werkst. 61(3), 221-226. DOI: $10.1007 / \mathrm{s} 00107-003-0389-2$

Balaban, M., and Uçar, G. (2001). "The correlation of wood acidity to its solubility by hot water and alkali," Holz. Roh. Werkst. 59(1-2), 67-70. DOI: $10.1007 / \mathrm{s} 001070050476$

Balaban, M., and Uçar, G. (2003). "Estimation of volatile acids in wood and bark," Holz. Roh. Werkst. 61(6), 465-468. DOI: 10.1007/s00107-003-0422-5

Bi, Z., Li, Z., and Yan, L. (2017). "Catalytic oxidation of lignin to dicarboxylic acid over the CuFeS2 nanoparticle catalyst," Green Process. Synth. 7(4), 306-315. DOI: 10.1515/gps-2017-0056

Clausen, C. A., Kenealy, W., and Lebow, P. K. (2008). "Oxalate analysis methodology for decayed wood," Int. Biodeter. Biodegr. 62(4), 372-375. DOI: 10.1016/j.ibiod.2008.04.001

Colom, X., Carrillo, F., Nogués, F., and Garriga, P. (2003). "Structural analysis of photodegraded wood by means of FTIR spectroscopy," Polym. Degrad. Stabil. 80(3), 543-549. DOI: 10.1016/S0141-3910(03)00051-X

Crivellaro, A., and Schweingruber, F. H. (2013). Atlas of Wood, Bark and Pith Anatomy of Eastern Mediterranean Trees and Shrubs with Special Focus on Cyprus, SpringerVerlag Berlin, Heidelberg, Germany. DOI: 10.1007/978-3-642-37235-3

Cronin, D. J., Zhang, X., Bartley, J., and Doherty, W. O. (2017). "Lignin depolymerization to dicarboxylic acids with sodium percarbonate," ACS Sustain. Chem. Eng. 5(7), 6253-6260. DOI: 10.1021/acssuschemeng.7b01208

Demesa, A. G., Laari, A., Turunen, I., and Sillanpää, M. (2015). "Alkaline partial wet oxidation of lignin for the production of carboxylic acids," Chem. Eng. Technol. 38(12), 2270-2278. DOI: 10.1002/ceat.201400660

El-Hefny, M., Salem, M. Z. M., Behiry, S. I., and Ali, H. M. (2020). "The potential antibacterial and antifungal activities of wood treated with Withania somnifera fruit 
extract, and the phenolic, caffeine, and flavonoid composition of the extract according to HPLC," Processes 8(1), Article number 113. DOI: 10.3390/pr8010113

Emandi, A. N. A., Ileana Vasiliu, C., Budrugeac, P., and Stamatin, I. (2011). "Quantitative investigation of wood composition by integrated FT-IR and thermogravimetric methods," Cellulose Chem. Technol. 45(9), 579-584.

Fackler, K., Stevanic, J. S., Ters, T., Hinterstoisser, B., Schwanninger, M., and Salmén, L. (2011). "FT-IR imaging microscopy to localise and characterise simultaneous and selective white-rot decay within spruce wood cells," Holzforschung 65(3), 411-420. DOI: $10.1515 / \mathrm{hf} .2011 .048$

Fengel, D. (1991). "Aging and fossilization of wood and its components," Wood Sci. Technol. 25(3), 153-177. DOI: 10.1007/BF00223468

Fengel, D., and Wegener, G. (1984). Wood-Chemistry, Ultrastructure, Reactions, Walter de Gruyter, Berlin, Germany.

Hamed, S. A. M. (2014). "Investigation of deterioration in archaeological wood used in architectural elements: Microscopic study," in Current Microscopy Contributions to Advances in Science and Technology, A. Méndez-Vilas (ed.), Spain Formatex Research Center, Badajoz, Spain, pp. 857-862.

Harvey, R., and Freedland, C. (1990). "Exhibition and storage of archaeological wood," in: Archaeological Wood: Properties, Chemistry and Preservation, R. M. Rowell, and R. T. Barbour (eds.), J. Am. Chem. Soc., Washington D.C., USA, pp. 399-418. DOI: 10.1021/ba-1990-0225.ch015

Huang, X., Kocaefe, D., Kocaefe, Y., Boluk, Y., and Pichette, A. (2012). "Study of the degradation behavior of heat-treated jack pine (Pinus banksiana) under artificial sunlight irradiation," Polym. Degrad. Stabil. 97(7), 1197-1214. DOI:

10.1016/j.polymdegradstab.2012.03.022

Kalberer, M., Yu, J., Cocker, D. R., Flagan, R. C., and Seinfeld, J. H. (2000). “Aerosol formation in the cyclohexene-ozone system," Environ. Sci. Technol. 34(23), 48944901. DOI: 10.1021/es001180f

Kenealy, W., Horn, E., Davis, M., Swaney, R., and Houtman, C. (2007). "Vapor-phase diethyl oxalate pretreatment of wood chips: Part 2. Release of hemicellulosic carbohydrates," Holzforschung 61(3), 230-235. DOI: 10.1515/HF.2007.041

Krilov, A., and Lasander, W. H. (1988). "Acidity of heartwood and sapwood in some Eucalypt species," Holzforschung 42(4), 253-258. DOI: 10.1515/hfsg.1988.42.4.253

Legrand, M., Preunkert, S., Oliveira, T., Pio, C. A., Hammer, S., Gelencsér, A., KasperGiebl, A., and Laj, P. (2007). "Origin of $\mathrm{C}_{2}-\mathrm{C}_{5}$ dicarboxylic acids in the European atmosphere inferred from year-round aerosol study conducted at a west-east transect," J. Geophys. Res. 112(D23S07), 1-14. DOI: 10.1029/2006JD008019

Lionetto, F., Del Sole, R., Cannoletta, D., Vasapollo, G., and Maffezzoli, A. (2012). "Monitoring wood degradation during weathering by cellulose crystallinity," Materials 5(10), 1910-1922. DOI: 10.3390/ma5101910

Mader, P. P., Cann, G., and Palmer, L. (1955). "Effects of polluted atmospheres on organic acid composition in plant tissues," Plant Physiol. 30(4), 318-323.

DOI: $10.1104 / p p .30 .4 .318$

Malhotra, S. S., and Khan, A. A. (1984) "Biochemical and physiological impact of major pollutants," in: Air Pollution and Plant Life, M. Treshow (ed.), John Wiley \& Sons Ltd., Chichester, United Kingdom, pp. 113-157.

Mansour, M. M. A., Hamed, S. A. E.-K. M., Salem, M. Z. M., and Ali, H. M. (2020). "Illustration of the effects of five fungi on Acacia saligna wood organic acids and 
ultrastructure alterations in wood cell walls by HPLC and TEM examinations," Appl. Sci. 10(8), Article number 2886. DOI: 10.3390/app10082886

Matteoli, U., Menchi, G., Staccioli, G., and Tamburini, U. (1992). “Acid groups structure in wood as shown using selective reduction," Holz. Roh. Werkst. 50(11), 438-440. DOI: $10.1007 / \mathrm{BF} 02662782$

Metsämuuronen, S., and Sirén, H. (2019). "Bioactive phenolic compounds, metabolism and properties: A review on valuable chemical compounds in Scots pine and Norway spruce," Phytochem. Rev. 18(3), 623-664. DOI: 10.1007/s11101-019-09630-2

Oberhofnerová, E., Pánek, M., and García-Cimarras, A. (2017). "The effect of natural weathering on untreated wood surface," Maderas- Cienc. Tecnol. 19(2), 173-184. DOI: 10.4067/S0718-221X2017005000015

Risholm-Sundman, M., Lundgren, M., Vestin, E., and Herder, P. (1998). "Emissions of acetic acid and other volatile organic compounds from different species of solid wood," Holz. Roh. Werkst. 56(2), 125-129. DOI: 10.1007/s001070050282

Rogge, W. F., Hildemann, L. M., Mazurek, M. A., Cass, G. R., and Simoneit, B. R. (1998). "Sources of fine organic aerosol. 9. Pine, oak, and synthetic log combustion in residential fireplaces," Environ. Sci. Technol. 32(1), 13-22. DOI: 10.1021/es960930b

Salem, M. Z. M., Abo Elgat, W. A. A., Taha, A. S., Fares, Y. G., and Ali, H. M., (2020). "Impact of three natural oily extracts as pulp additives on the mechanical, optical, and antifungal properties of paper sheets made from Eucalyptus camaldulensis and Meryta sinclairii wood branches," Materials 13(6), Article number 1292. DOI: 10.3390/ma13061292

Sivrikaya, H., and Can, A. (2016). "Effect of weathering on wood treated with tall oil combined with some additives," Maderas- Cienc. Tecnol. 18(4), 723-732. DOI: 10.4067/S0718-221X2016005000063

Sirén, H., Riikonen, P., Yang, G., Petton, A., Paarvio, A., and Böke, N. (2015). "Hydrophilic compounds in liquids of enzymatic hydrolyzed spruce and pine biomass," Anal. Biochem. 485, 86-96. DOI: 10.1016/j.dib.2015.08.026

Sundqvist, B. (2004). Color Changes and Acid Formation in wood During Heating, Doctoral Thesis, Divisions of Wood Material Science, Luleå University of Technology, Skellefteå, Sweden.

Sundqvist, B., Karlsson, O., and Westermark, U. (2006). "Determination of formic-acid and acetic acid concentrations formed during hydrothermal treatment of birch wood and its relation to colour, strength and hardness," Wood Sci. Technol. 40(7), 549-561. DOI: 10.1007/s00226-006-0071-z

Straže, A., Torkar, S., Tišler, V., and Gorišek, Ž. (2003). "Changes of ashwood pH-value during conventional drying," Zbornik Gozdarstva in Lesarstva (71), 107-124.

Tolvaj, L., and Faix, O. (1995). "Artificial aging of wood monitored by DRIFT spectroscopy and CIE $L * a * b *$ color measurements," Holzforschung 49(5), 397-404. DOI: $10.1515 / \mathrm{hfsg} .1995 .49 .5 .397$

Temiz, A., Terziev, N., Jacobsen, B., and Eikenes, M. (2006). "Weathering, water absorption, and durability of silicon, acetylated, and heat-treated wood," J. Appl. Polym. Sci. 102(5), 4506-4513. DOI: 10.1002/app.24878

Uçar, G., and Uçar, M. B. (2012). "The estimation of acidic behavior of wood by treatment with aqueous $\mathrm{Na}_{2} \mathrm{HPO}_{4}$ solution," J. Anal. Methods. Chem. 2012, Article ID 496305. DOI: $10.1155 / 2012 / 496305$ 
Xie, Y., Krause, A., Mai, C., Militz, H., Richter, K., Urban, K., and Evans, P. D. (2005). "Weathering of wood modified with the N-methylol compound 1, 3-dimethylol-4, 5dihydroxyethyleneurea," Polym. Degrad. Stabil. 89(2), 189-199. DOI:

10.1016/j.polymdegradstab.2004.08.017

Yaşar, S. (2018). "Volatile acid content of some maquis species," Bartın Orman Fakültesi Dergisi 20(1), 67-72. DOI: 10.24011/barofd.394389

Article submitted: May 4, 2020; Peer review completed: June 28, 2020; Revised version received and accepted: June 30, 2020; Published: July 8, 2020.

DOI: 10.15376/biores.15.3.6506-6525 